\title{
Sciences
}

Vol. 06, No. 03, pp. 107-126, September 2013

\section{NONLINEAR ANALYSIS OF SIMPLY SUPPORTED COMPOSITE STEEL - CONCRETE BEAM}

\author{
Amer M. Ibrahim ${ }^{1}$, Qussay W. Ahmed ${ }^{2}$ \\ ${ }^{1,2}$ College of engineering, Diyala University \\ Email: amereng05@yahoo.com ${ }^{1}$, qussay_2006@yahoo.com ${ }^{2}$ \\ (Received: 18/9/2011; Accepted: 31/1/2013)
}

\begin{abstract}
This paper presents a nonlinear finite element computer program. ANSYS version 12.0 developed for the analysis of composite steel-concrete beam. A threedimensional finite element (FE) model has been developed in this work. The analytical results of load-deflection response have been compared with available experimental tests. In general good agreement between the finite element solutions and experimental results have been obtained. Parametric studies have been carried out to investigate the effect of some important material and geometrical parameters. These parameters included the effect of shear connectors number, concrete grade, thickness to width ratio of concrete slab, the ultimate load for shear connector and effect of yield strength of Steel beam. It was found that, as the compressive strength of concrete increases from $20 \mathrm{MPa}$ to $70 \mathrm{MPa}$ the ultimate load increases by about $20 \%$ and also an increase in the thickness to width ratio $(\mathrm{t} / \mathrm{B})$ of concrete slab from 0.1 to 0.3 lead to increase in the ultimate load by about $43 \%$.
\end{abstract}

Keywords: - Composite beams; Steel-concrete; Finite Element modeling; Nonlinear analysis.

\section{INTRODUCTION}

Concrete and structural steel are the two most widely used materials in the construction industry. Whenever such materials are used individually, there are inherent weaknesses where concrete is inefficient in resisting tensile load and slender structural steel sections are susceptible to load buckling. However, when they are combined together to form so called composite construction, the merits of these two materials are optimally used. The efficiency of composite construction is increased significantly where concrete is utilized for compression and steel in tension. Furthermore, concrete provides corrosion resistance and 
fire protection to steel sections and reduces the susceptibility of slender steel sections to buckling modes ${ }^{(1)}$.

The use of steel-concrete composite beams has gained popularity in the last century thanks to its ability to well combine the advantages of both steel and concrete. Composite members exhibit enhanced strength and stiffness when compared to the contribution of their components acting separately, and represent a competitive structural solution in many civil engineering applications, such bridges and buildings. In the 40s and 50s of the last century the first studies on composite beam behavior underlined that the relative displacement between the steel beam and the reinforced concrete slab requires to be included in the beam model for an adequate representation of the composite action ${ }^{(2)}$. In fact, composite action depends on the interaction between three main components: the reinforced concrete slab, the steel profile, and the shear connection.

The major advantage of steel-concrete composite members over the, conventional reinforced-concrete members is that the cross-section can be significantly reduced, if composite action can be obtained between steel and concrete. Since natural bond may not be effective for composite action, several different types of shear connection systems are provided for the steel-concrete composite members to obtain the composite action. However, the full-composite action cannot be obtained since the steel-concrete composite members show partial-interaction behavior due to the deformation and slip at the interface under the applied loads ${ }^{(3)}$.

\section{FINITE ELEMENT MODELING}

The present study utilized the finite element program ANSYS version 12. A threedimensional finite element model has been developed to simulate the geometric and material nonlinear behavior of composite beam. Materials Representation:-

ANSYS.12 program was used to analyze the three dimensional model. The concrete was modeled by using the 8-noded isoperimetric brick elements (SOLID 65). The element is defined by eight nodes having three degrees of freedom at each node, translation in the $\mathrm{x}, \mathrm{y}$, and $\mathrm{z}$ directions. The element is capable of modifying cracks in tension and in three orthogonal directions, crushing in compression, and plastic deformation.

The steel bars were modeled using axial members (LINK8). This element can be used to model trusses, sagging cables, links, springs, etc. The 3-D spar element is a uniaxial tension compression element with three degrees of freedom at each node: translations of the 
nodes in $\mathrm{x}, \mathrm{y}$, and $\mathrm{z}$-directions. As in a pin-jointed structure, no bending of the element is considered. Plasticity, creep, swelling, stress stiffening, and large deflection capabilities are included.

The steel I-beam was modeled using isoperimetric shell elements (SHELL43) with 4nodes. . SHELL43 is well suited to model linear, warped, moderately-thick shell structures. The element has six degrees of freedom at each node: translations in the nodal $\mathrm{x}, \mathrm{y}$, and $\mathrm{z}$ directions and rotations about the nodal $\mathrm{x}, \mathrm{y}$, and $\mathrm{z}$ axes. The deformation shapes are linear in both in-plane directions. For the out-of-plane motion, it uses a mixed interpolation of tonsorial components. The element has plasticity, creep, stress stiffening, large deflection, and large strain capabilities.

A (COMBIN39) nonlinear spring elements was used to represent the shear connectors with link8. The element COMBIN 39 is a unidirectional element (or nonlinear spring) with nonlinear generalized force deflection capability that can be used in any analysis. The element has a large displacement capability for which there can be two or three degrees of freedom at each node. The element is defined by two nodes and a generalized force deflection curve.

For nonlinear solution, ANSYS "Newton-Raphson" approach to solve nonlinear problems .in this approach, the load is subdivided into a series of the load increments. The load increments can be applied over several load steps ${ }^{(4)}$. A typical finite element mesh and stud, Steel reinforcement modeling for the composite beam is shown in figures (1) and (2).

\section{3- MATERIAL MODELING}

\section{3-1 Concrete in Compression}

The concrete is assumed to be homogeneous and initially isotropic. The compressive uniaxial stress-strain relationship for concrete model is obtained by using the following equations to compute the multi-linear isotropic stress-strain curve for the concrete as shown in Fig. (3). The multi-linear curves were used to help with convergence of the nonlinear solution algorithm. The crack modeling depends on smeared cracking modeling ${ }^{(5)}$.

$$
\begin{aligned}
& f_{c}=\varepsilon E_{c} \text { for } 0 \leq \varepsilon \leq \varepsilon_{1} \\
& f_{c}=\frac{\varepsilon E_{c}}{1+\left(\frac{\varepsilon}{\varepsilon_{0}}\right)^{2}} \quad \text { for } \varepsilon_{1} \leq \varepsilon \leq \varepsilon_{0}(2) \\
& \varepsilon_{0}=\frac{2 f_{c}}{E_{c}} \\
& \quad \text { for } \varepsilon_{0} \leq \varepsilon \leq \varepsilon_{c u}(3)
\end{aligned}
$$

Where 
$f_{c}=$ stress at any strain $\varepsilon, \mathrm{N} / \mathrm{mm}^{2}, \varepsilon_{0}=$ strain at the ultimate compressive strength $f_{c}^{\prime} . \varepsilon_{c u}=$ ultimate compressive strain, $\varepsilon_{1}=$ strain corresponding to $0.3 f_{c}^{\prime}$

The multi-linear isotropic stress- strain implemented requires the first point of the curve to be defined by the user. It must satisfy Hooke's law:

$$
\begin{aligned}
& E=\sigma / \varepsilon(4) \\
& \sigma=0.3 f_{c}^{\prime}
\end{aligned}
$$

\section{3-2 Concrete in Tension}

The stress-strain relationship for concrete in tension assumes that the tensile stress increases linearly with an increase in tensile strain up to concrete cracking. After concrete cracking, the tensile stress decreases linearly to zero as the concrete softens. The bond between the concrete and reinforcing bars was simulated approximately by the tension stiffening model, which defines the stress-strain relationship for concrete in tension after cracking. For heavily reinforced concrete slabs, the total strain at which the tensile stress is zero is usually taken as 10 times the strain at failure in the tension stiffening model. However, it has been found that this value is not adequate for concrete slabs in composite beams. In the present study, a total strain of 0.1 was used for reinforced concrete slabs in composite beams, as suggested by (6).

\section{3-3 Steel Beam}

Von Mises yield criterion with isotropic hardening rule (multi-linear work hardening material) is used to represent the steel beam (flanges and web) behavior. The stress-strain relation is linearly elastic up to yield, perfectly plastic between the elastic limit and the beginning of strain hardening as shown in Fig. (4) an follows the constitutive law for the strain-hardening branch ${ }^{(7)}$.

$$
\sigma=f_{y}+E_{h}\left(\varepsilon-\varepsilon_{h}\right)\left(1-E_{h} \frac{\varepsilon-\varepsilon_{h}}{4\left(f_{u}-f_{y}\right)}\right)(6)
$$

\section{3-4 Reinforcing Bars}

Since the reinforcing bars are normally long and relatively slender, they can generally be assumed to be capable of transmitting axial forces only. For the finite element models, the uniaxial stress-strain relation for steel is idealized as a bilinear curve, representing elasticplastic behavior with strain hardening. This relation is assumed to be identical in tension and in compression, as shown in Fig. (5). 
In the present work, the strain hardening modulus $\left(\mathrm{E}^{\mathrm{T}}\right)$ is assumed to be $(0.02 \mathrm{Es})$. This value was selected to avoid convergence problems during iteration.

\section{3-5 Shear Connectors}

The main function of shear connectors are to transmit longitudinal shear force between concrete beam and steel this is represented by the following function Where

$$
F_{d}=a\left(1-e^{-b u_{c}}\right)(7)
$$

$F_{d}=$ shear force on a stud shear connector, $u_{c}=$ the slip, $\mathrm{b}=$ constant,$\quad \mathrm{a}=$ ultimate shear resistance of stud shear connector.

\section{4- BEAM AND MATERIALS}

The geometry and the Details of cross section for composite beam ${ }^{(8)}$ are shown in (Figs. 6, 7). The length of this simple composite steel-concrete beam was $(5490 \mathrm{~mm})$. This beam consisted of a concrete slab at the top, steel I-section beam at the bottom and stud top, steel I section beam at the bottom and stud connectors to connect the concrete slab with the steel beam. The concrete slab had a depth of connectors to connect the concrete slab with the (152 $\mathrm{mm})$ and a width of $(1220 \mathrm{~mm})$ whereas the steel I-section beam had a depth of $(305 \mathrm{~mm})$, a flange depth of $(18 \mathrm{~mm})$, flange width of $(152 \mathrm{~mm})$ and web thickness of $(10 \mathrm{~mm})$. The external concentrated load was applied to the specimen at its midspan. Asummary of the materials properties of the selected specimens are listed in Table (1).

\section{5- RESULTS AND DISCUSSION}

\section{5-1 Load Deflection Curve}

To compare the load-deflection curve of F.E.Model together with experimental test curve for Yam-Chapman's composite test beam, it is necessary to measure the vertical displacement (deflection) at centerline of bottom face of the F.E.Model, and vertical displacement due to applied load at end sub step, as shown in Fig. (8) and Fig.(9) the experimental and numerical curves obtained for the composite beam.The midspan externally applied load is plotted against the mid span deflection. For this beam, the failure load obtained by experimental work and that predicted by the finite element solutions are listed in Table (2). It can be noted from Fig.(9) and Table(2) that the finite element solutions are in good agreement with the experimental results throughout the entire range of behavior and it shows that, the percent discrepancy of F.E.Model corresponding to test beam is only $(2.67 \%)$. 


\section{5-2 Stress Distribution Along Cross -Section}

The normal stress distribution along the depth of the section is shown in Fig.(10). The selected section is close to the mid-span of the beam and loaded with maximum shear and maximum moment. For composite beam, the pattern of normal stress distribution at $(30 \%)$ and $(50 \%)$ of the ultimate load is almost linear along the concrete slab and the steel I-beam as shown Fig. (10).At (75\%) of the ultimate load the tensile stress at the bottom face of the concrete slab is reduced, because of cracking. Also, the normal stress at steel I-beam bottom face approaches yielding. With higher load levels and up to ultimate load, the compressive stress at top of concrete slab is continuously increased while the tensile stress at bottom of concrete slab is reduced to zero. While, a plastic stress distribution is noticed at the bottom parts of the steel I-beam at stages close to ultimate load.

\section{5-3 End Slip Beam}

Numerically, the relative movement (shear slip) between concrete and I-Steel beam was measured from the difference between the nodal displacements, in x-direction (Ux), at concrete and I-steel beam, as shown in Fig. (11).

\section{5-4 PARAMETRIC STUDY}

\section{5-4-1: Effect of Compressive Strength for Concrete}

To study the effect of concrete compressive strength $\mathrm{f}_{\mathrm{c}}^{\prime}$ of the slab on the behavior of composite steel-concrete beam, composite beam has been analyzed for different values of concrete compressive strength. These value were $(20,27.1,30,40,50,60$, and 70)MPa. Fig. (12) shows the effect of compressive strength concrete slab on the load-deflection behavior of the selected beam. The figure indicates that the stiffness of beam increases with the increase of $\mathrm{f}_{\mathrm{c}}^{\prime} \mathrm{up}$ to $50 \mathrm{MPa}$. The responses obtained for values of $\mathrm{f}_{\mathrm{c}}^{\prime}$ equal to 50, 60 and $70 \mathrm{MPa}$ are almost similar. Therefore, the increase in concrete compressive strength beyond $50 \mathrm{Mpa}$ is insignificant this is due to the fact that the failure is crushing type of failure for $\mathrm{f}_{\mathrm{c}}^{\prime}$ is less than $50 \mathrm{MPa}$ and yielding of steel beam forf ${ }_{\mathrm{c}}^{\prime}$ greater than $50 \mathrm{MPa}$.In addition, The Fig.(12) and table (3) shows that the ultimate load capacity increases as $\mathrm{f}_{\mathrm{c}}^{\prime}$ is increased. For values of $\mathrm{f}_{\mathrm{c}}^{\prime}$ ranging between 20 and $40 \mathrm{MPa}$ the numerical analyses show that the type of failure wascrushing of concrete slab prio to yielding of the steel beam. Therefore, the increase in the value of the compressive strength results in a substantial increase in the ultimate moment. 
While forvalues of $\mathrm{f}_{\mathrm{c}}^{\prime}$ ranging between 50 and $70 \mathrm{MPa}$, the numerical analyses reveal that the steel beam yields at failure before crushing of concrete slab takesplace.

\section{5-4-2 Effect of Shear Connector Number}

In order to investigate the effect shear connectors on the load-deflection behavior, six different numbers of shear connectors were taken for the finite element analysis of composite steel-concrete beam. The selected number of shear connectors were 38, 76, 100, and 125studs. Fig. (13) and table (4) show the effect of the number of shear connectors on the load-deflection behavior of the selected composite steel-concrete beam. The figure indicates that the stiffness of the beam increases with increasing number of shear connectors up to 100 studs. The response obtained using a number of shear connectors more than 100 studs was almost similar to that with 125 studs. Therefore, for this beam the use of a number more than 125 studs has an insignificant effect of the predicted behavior since the mode of failure was achieving the ultimate shear capacity of stud when the number of studs are less than 38,76 and 100 while the failure mode was yielding of steel beam when the number of studs exceeds 100.

\subsection{3: Effect of Ratio of Depth to Width of Concrete Slab}

Effect of the ratio of concrete slab depth to its width on the load-deflection behavior of composite beams and their ultimate moment are illustrated in Fig. (14). Different ratios depth to width for concrete slab of composite beam were taken in the finite element analysis. The selected ratios were $(0.1,0.12,0.15,0.2,0.25$ and 0.3$)$. In choosing these ratios, the total area of concrete slab was kept constant at $\left(185440 \mathrm{~mm}^{2}\right)$. Fig. (14) and table (5) shows the effect of depth to width ratio on the load-deflection behavior of selected beam. In this figure, the stiffness of beam is increased by increasing the depth to width ratio of concrete slab. In this study, the type of failure for all ratios was yielding of steel beam because of the presence of large concrete area. Values of compressivestrength of concrete and yield stress of steel beam were keptconstants at (27.1 MPa) and (239 MPa) respectively.

\section{5-4-4 Effect of Ultimate Strength of Shear Connector (a):}

For composite beam, all the numerical tests described up to this point have been conducted by setting the values of the constants (a) and (b) to $(32 \mathrm{kN})$ and $\left(5 \mathrm{~mm}^{-1}\right)$ respectively, According to push-out test results, these values have been selected using (Eq.7) 
to obtain the best fit shear connectors response. Numerical analyses with different values for the constants (a) conducted, while the other constant (b) held fixed in order to isolate the effects of constant considered. Four different values for the constant (a) were used. While, the constant (b) was kept equal to $\left(5 \mathrm{~mm}^{-1}\right)$. Results of the analysis are shown in Fig. (15) and table (6), The selected values for the constant (a) ranged between $10 \mathrm{kN}$ and $50 \mathrm{kN}$. The numerical results indicate that the higher value of constant (a) results in a higher limited slipping stress. Therefore, higher values of the constant (a) mean that the reduction in composite action will be delayed. Through this study, it can be noted stiffer of load-deflection responses are obtained with higher values of the constant (a). Also, the ultimate load increases by about $39 \%$ as the constant (a) is increased from $10 \mathrm{kN}$ to $40 \mathrm{kN}$, as shown in Table (6).

\section{5-4-5 Effect of Yield Strength of Steel Beam:}

To study the effect of yield strength for steel beam, different yield strengths are considered. These values are (220MPa, 239MPa, 260MPa, $280 \mathrm{MPa}, 300 \mathrm{MPa}$ and 320 MPa). Fig. (16) showthe response of the deflection for various yield strength for steel beam. From this Figure and table (7), it can be observed that an increase in yield strength of steel beam from $239 \mathrm{MPa}$ to $320 \mathrm{MPa}$ causes an increase in ultimate load capacity (8\%) and a decrease in ductility index in (40\%) while decreasing yield strength of steel beam from 239 MPa to 220 Mpa cause a decrease in ultimate load capacity (6.5\%) and increase in ductility index $(22.7 \%)$.

\section{CONCLUSIONS:-}

The main concluding remarks that have been achieved from theresults of the finite element analysis may be summarized as:

1- The finite element model used in the present work is able to simulate the behavior of composite steel-concrete beams in flexure. The analytical studied indicated that the load-deflection behavior and the ultimate loads are in good agreement with the published experimental results. The ratio of the predicted experimental ultimate load to the numerical ultimate load has an average value of (0.97) for composite steelconcrete beams in flexure. These results reveal the accuracy and efficiency of the 
developed computer program (ANSYS version 12.0) in predicting the behavior and ultimate load of composite steel-concrete beams.

2- According to the results obtained from the numerical analyses of composite steelconcrete beams, it was found that the Increasing concrete compressive strength for the concrete slab beyond $50 \mathrm{MPa}$ has insignificant effect on the ultimate capacity of selected beam, while, a decrease of concrete compressive strength from $50 \mathrm{MPa}$ to 20 MPa decreases the ultimate load a bout (18\%).

3- This study shows that by increase number of shear connector from (38 to 125) studs the ultimate load capacity increased about $(24.6 \%)$.

4- The stiffness of composite beams was increased by increasing the ratio of the depth to width of concrete slab ( $\mathrm{t} / \mathrm{B})$, with keeping the total area of concrete slab constant and it was found that as the (t/B) ratio is increased from 0.1 to 0.3 the ultimate load increases by about $43 \%$.

5- It was found that the load-deflection response of composite beams is stiffer for higher value of constant $(a)$, which represents the ultimate shear capacity of studs. It was also noticed that when the constant (a) is increased from $10 \mathrm{kN}$ to $50 \mathrm{kN}$, the ultimate load increases by about (32\%).

6- An increase in yield strength of steel beam from $239 \mathrm{MPa}$ to $320 \mathrm{MPa}$ causes an increase in ultimate load capacity (8\%) and a decrease in ductility index in (40\%) while decreasing yield strength of steel beam from $239 \mathrm{MPa}$ to $220 \mathrm{Mpa}$ cause a decrease in ultimate load capacity $(6.5 \%)$ and increase in ductility index $(22.7 \%)$.

\section{REFERENCES:}

1- Heong. T. T., 2003, "Design Appraisal of Steel-Concrete Composite Joints" A Thesis National University of Singapore.

2- Ranzi G., and Zona A., 2007, "A steel-concrete composite beam model with partial interaction including the shear deformability of the steel component" Engineering Structures, Vol.29, pp. 3026-3041.

3- Jeong,Y., KimaH., and Kimb S., 2005,"Partial-interaction analysis with push-out tests" Journal of Constructional Steel Research Vol. 61, 1318-1331. 
4- Nethercot D. A., 2002, "The Importance of Combining Experimental and Numerical Study in Advancing Structural Engineering Under-standing", Journal of Constructional Steel Research, No. 58, pp. 1283-96.

5- Desayi, P., and Krishnan, S., 1964,"Equation for the Stress-Strain Curve of Concrete", Journal of the American Concrete Institute, Vol. (61), pp. 345- 350.

6- Liang Q.Q., Uy B., Bradford M.A., and Ronagh H.R., 2004, "Strength analysis of steel-concrete composite beams in combined bending and shear" Journal of structural Engineering- ASCE, Vol. 60, pp. 1109 - 1128.

7- Kemp A.R., Dekker N.W., and TrincheroP., 1995 "Differences in Inelastic Properties of Steel and Composite Beams", Journal of Constructional Steel Research, No. 34, pp. 187-206.

8- Yam, L. C. P. and Chapman,J. C., 1968, "The inelastic behaviour of simply supported composite beams of steel and concrete", Proc. Instn. Civ. Engrs, Vol. 41, pp. 651-683.

Table (1): Material properties.

\begin{tabular}{|c|c|c|}
\hline Material & Property & Value \\
\hline \multirow{4}{*}{ Structural steel } & Yield stress, $\mathrm{f}_{\mathrm{sy}}\left(\mathrm{N} / \mathrm{mm}^{2}\right)$ & 239 \\
\hline & $\begin{array}{l}\text { Ultimate strength, } \mathrm{f}_{\mathrm{su}} \\
\left(\mathrm{N} / \mathrm{mm}^{2}\right)\end{array}$ & 418 \\
\hline & $\begin{array}{l}\text { Young's modulus, } E_{\mathrm{s}} \\
\left(\mathrm{N} / \mathrm{mm}^{2}\right)\end{array}$ & 203000 \\
\hline & Poisson's ratio & 0.3 \\
\hline \multirow{4}{*}{$\begin{array}{l}\text { Reinforcing } \\
\text { bar }\end{array}$} & Yield stress, $\mathrm{f}_{\mathrm{y}}\left(\mathrm{N} / \mathrm{mm}^{2}\right)$ & 230 \\
\hline & Ultimate strength $\mathrm{f}_{\mathrm{u}}\left(\mathrm{N} / \mathrm{mm}^{2}\right)$ & 414 \\
\hline & $\begin{array}{l}\text { Young's modulus, } E_{c} \\
\left(\mathrm{~N} / \mathrm{mm}^{2}\right)\end{array}$ & 202000 \\
\hline & Poisson's ratio & 0.3 \\
\hline \multirow{4}{*}{ Concrete } & $\begin{array}{l}\text { Compressive strength } \\
f_{c}^{\prime}\left(\mathrm{N} / \mathrm{mm}^{2}\right)\end{array}$ & 27.1 \\
\hline & Tensile strength, $\mathrm{f}_{\mathrm{ct}}\left(\mathrm{N} / \mathrm{mm}^{2}\right)$ & 2.71 \\
\hline & $\begin{array}{l}\text { Young's modulus, } E_{c} \\
\left(\mathrm{~N} / \mathrm{mm}^{2}\right)\end{array}$ & 29670 \\
\hline & Poisson's ratio, & 0.2 \\
\hline \multirow{3}{*}{ Shear connector } & Number of studs & 76 \\
\hline & Number of rows & 2 \\
\hline & Young's modulus, Es & 205000 \\
\hline
\end{tabular}




\begin{tabular}{|l|c|}
\hline$\left(\mathrm{N} / \mathrm{mm}^{2}\right)$ & \\
\hline Poisson's ratio, & 0.3 \\
\hline Diameter $(\mathrm{mm})$ & 19 \\
\hline Overall length $(\mathrm{mm})$ & 102 \\
\hline $\mathrm{a}(\mathrm{kN})$ & 32 \\
\hline $\mathrm{b}\left(\mathrm{mm}^{-1}\right)$ & 5 \\
\hline
\end{tabular}

Table (2): Ultimate loads from experimental test and Finite element analysis.

\begin{tabular}{|c|c|c|c|c|}
\hline \multirow{2}{*}{$\begin{array}{c}\text { Analytic } \\
\text { and test } \\
\text { beam }\end{array}$} & $\left(\mathrm{P}_{\mathrm{u}}\right)_{\text {EXP. }}$ & $\left(\mathrm{P}_{\mathrm{u}}\right)_{\mathrm{FEM} .}$ & $\frac{\left(\mathrm{P}_{\mathrm{u}}\right)_{\text {EXP. }}}{\left(\mathrm{P}_{\mathrm{u}}\right)_{\mathrm{FEM} .}}$ & $\begin{array}{c}\text { Error } \\
\text { ratio }\end{array}$ \\
\cline { 2 - 5 } $\begin{array}{c}\text { Composite } \\
\text { Beam }\end{array}$ & 448 & 460 & 0.974 & $2.67 \%$ \\
\hline
\end{tabular}

Table (3): Analytical ultimate loads obtained for different grade of concrete.

\begin{tabular}{|c|c|c|}
\hline $\begin{array}{c}\text { Concrete } \\
\text { grade }(\mathrm{MPa})\end{array}$ & $\begin{array}{c}\text { Ultimate load } \\
(\mathrm{kN})\end{array}$ & $\begin{array}{c}\text { Ratio } \\
\left(\mathrm{P}_{\mathrm{u}} / \mathrm{P}_{20}\right)\end{array}$ \\
\hline 20 & 408 & 1 \\
\hline 27.1 & 460 & 1.12 \\
\hline 30 & 463 & 1.13 \\
\hline 40 & 474 & 1.16 \\
\hline 50 & 482 & 1.18 \\
\hline 60 & 484 & 1.186 \\
\hline 70 & 492 & 1.2 \\
\hline
\end{tabular}

Table (4):Analytical ultimate loads obtained for different number of studs.

\begin{tabular}{|c|c|c|}
\hline $\begin{array}{c}\text { No. of shear } \\
\text { connector }\end{array}$ & $\begin{array}{c}\text { Ultimate load } \\
(\mathrm{kN})\end{array}$ & $\begin{array}{c}\text { Ratio } \\
\left(\mathrm{P}_{\mathrm{u}} / \mathrm{P}_{38}\right)\end{array}$ \\
\hline 38 & 397 & 1 \\
\hline 76 & 460 & 1.15 \\
\hline 100 & 476 & 1.19 \\
\hline 125 & 495 & 1.24 \\
\hline
\end{tabular}


Table (5): Analytical ultimate loads obtained for different values of concrete slab depth to width ratios.

\begin{tabular}{|c|c|c|}
\hline $\begin{array}{c}\text { Depth to } \\
\text { width ratio }\end{array}$ & $\begin{array}{c}\text { Ultimate load } \\
(\mathrm{kN})\end{array}$ & $\begin{array}{c}\text { Ratio } \\
\left(\mathrm{P}_{\mathrm{u}} / \mathrm{P}_{0.1}\right)\end{array}$ \\
\hline 0.1 & 417 & 1 \\
\hline 0.12 & 460 & 1.103 \\
\hline 0.15 & 503 & 1.206 \\
\hline 0.2 & 522 & 1.252 \\
\hline 0.25 & 560 & 1.343 \\
\hline 0.3 & 596 & 1.429 \\
\hline
\end{tabular}

Table (6): Analytical ultimate loads obtained for different values of constant (a).

\begin{tabular}{|c|c|c|}
\hline $\begin{array}{c}\text { Constant }(\mathrm{a}) \\
(\mathrm{kN})\end{array}$ & $\begin{array}{c}\text { Ultimate load } \\
(\mathrm{kN})\end{array}$ & $\begin{array}{c}\text { Ratio } \\
\left(\mathrm{P}_{\mathrm{u}} / \mathrm{P}_{10}\right)\end{array}$ \\
\hline 10 & 357 & 1 \\
\hline 20 & 446 & 1.249 \\
\hline 32 & 460 & 1.288 \\
\hline 40 & 496 & 1.389 \\
\hline 50 & 473 & 1.324 \\
\hline
\end{tabular}

Table (7): Analytical ultimate loads obtained for different values of yield strength of steel beam.

\begin{tabular}{|c|c|c|}
\hline $\begin{array}{c}\text { Yield } \\
\text { strength } \\
(\mathbf{M p a})\end{array}$ & $\begin{array}{c}\text { Ultimate load } \\
(\mathbf{k N})\end{array}$ & $\begin{array}{c}\text { Ratio } \\
\left(\mathbf{P}_{\mathbf{u}} / \mathbf{P}_{\mathbf{2 2}}\right)\end{array}$ \\
\hline $\mathbf{2 2 0}$ & 430 & 1 \\
\hline $\mathbf{2 3 9}$ & 460 & 1.07 \\
\hline $\mathbf{2 6 0}$ & 470 & 1.09 \\
\hline $\mathbf{2 8 0}$ & 482 & 1.12 \\
\hline $\mathbf{3 0 0}$ & 490 & 1.14 \\
\hline $\mathbf{3 2 0}$ & 497 & 1.15 \\
\hline
\end{tabular}




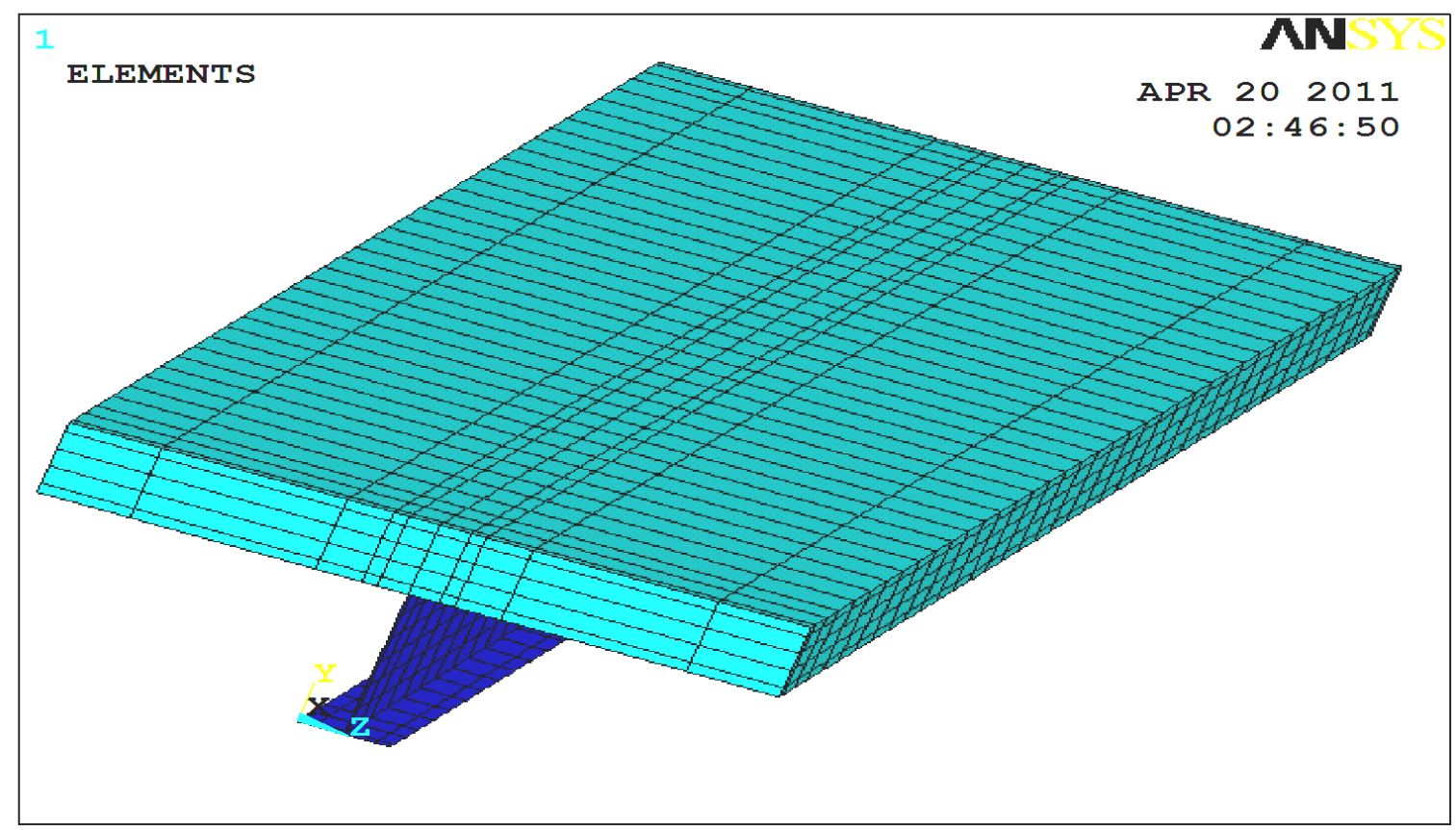

Figure (1): Typical finite element mesh for composite beam.

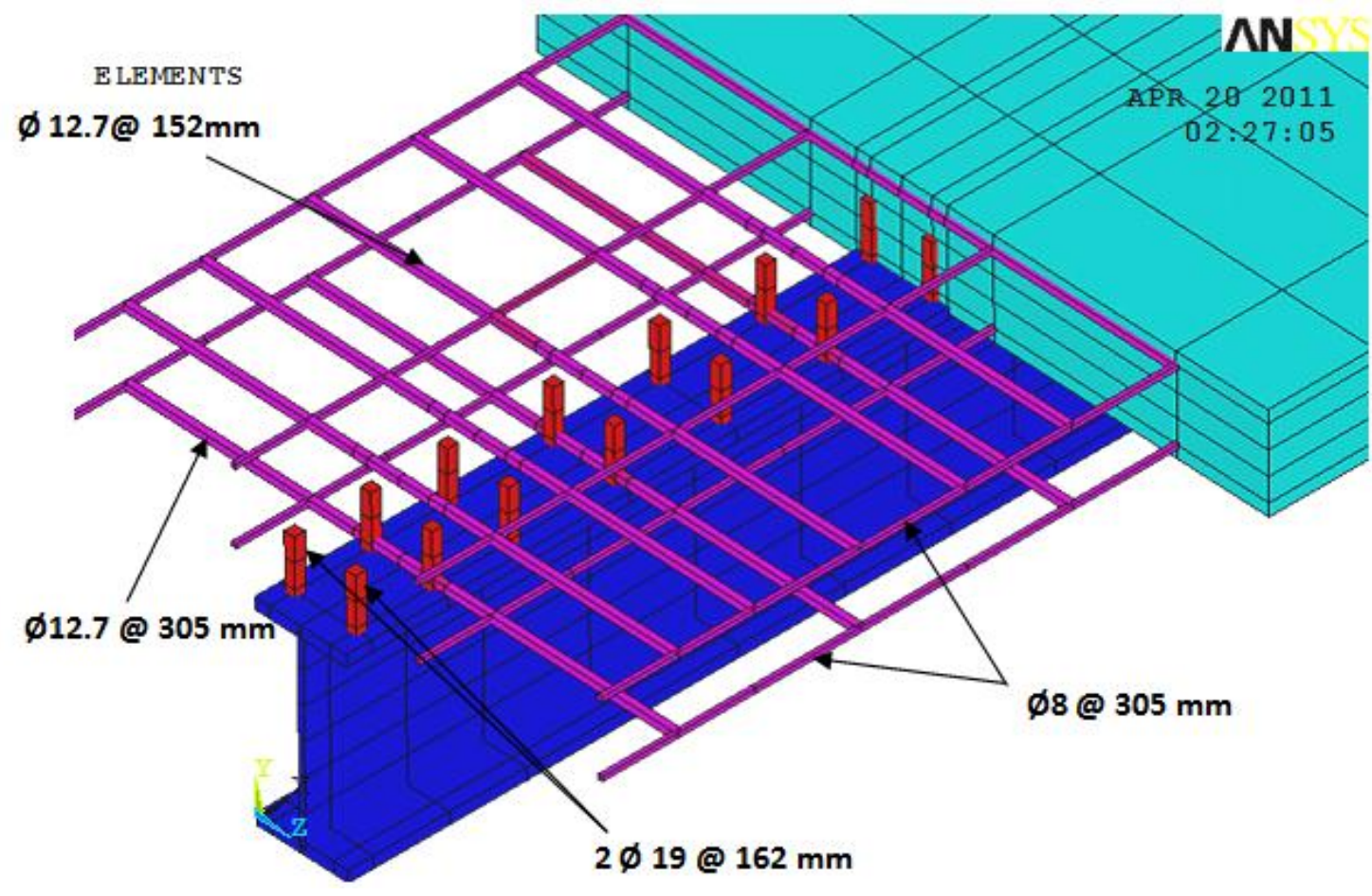

Figure (2): Shear connectors and reinforcement modeling in ANSYS. 


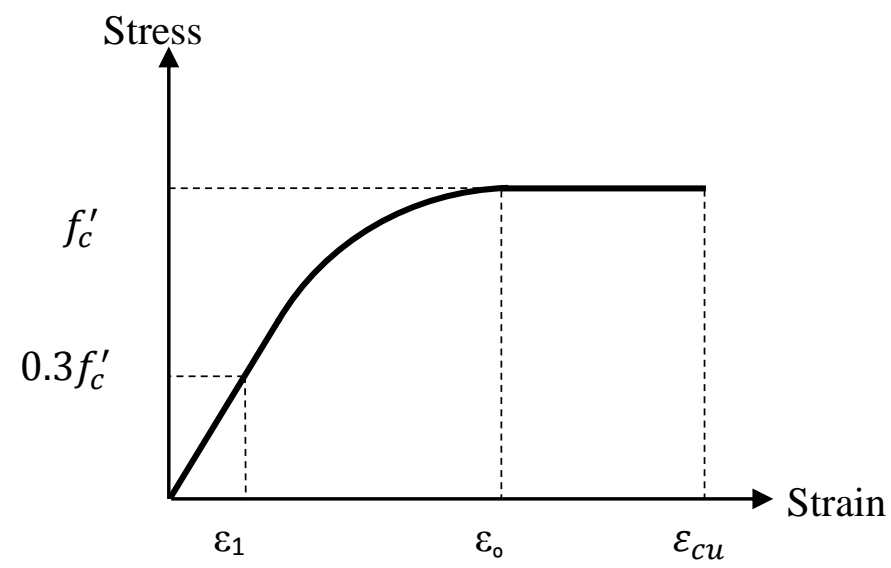

Figure (3): Stress - strain curve for concrete in compression.

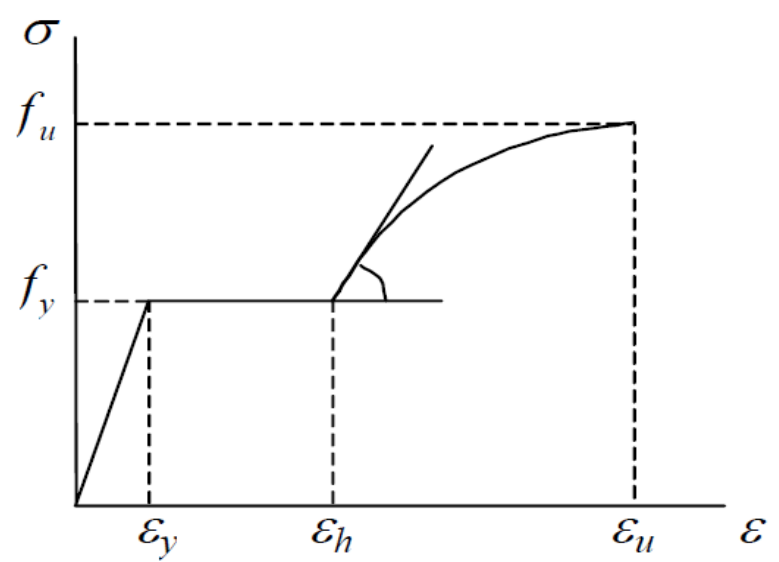

Figure (4): Idealized stress-strain for steel.

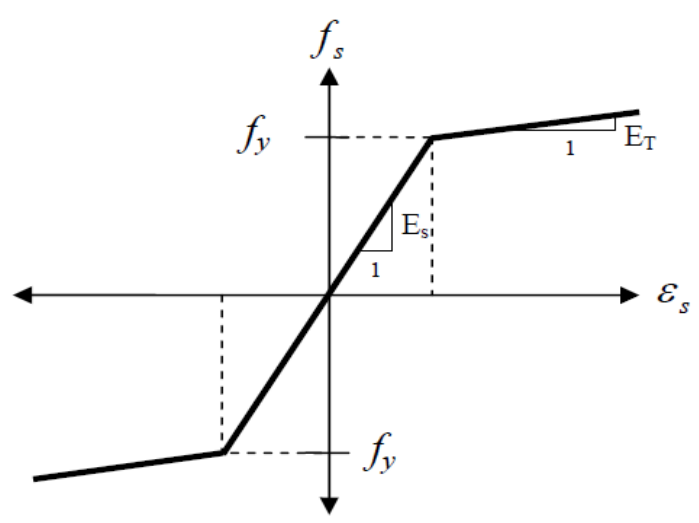

Figure (5): Modeling of reinforcing bars. 


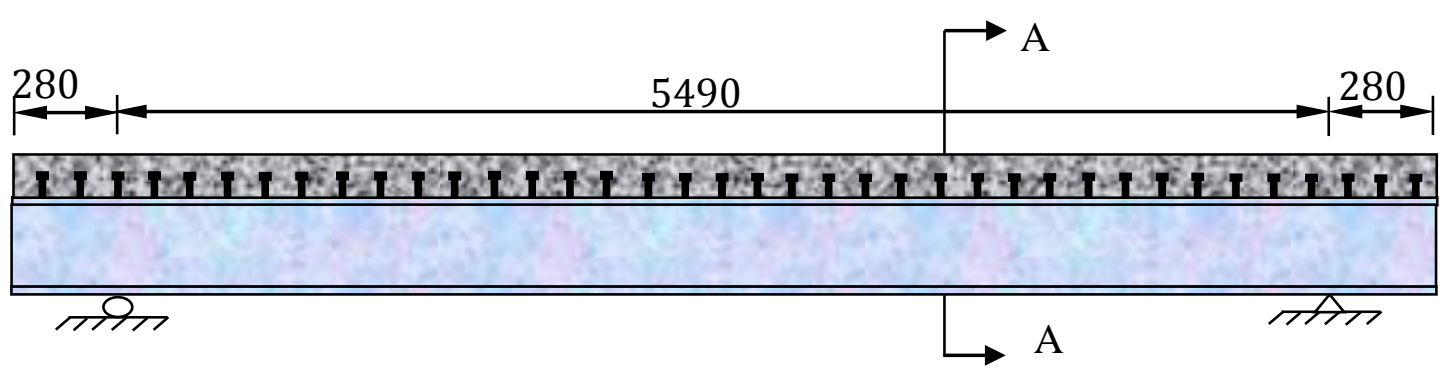

Figure (6): Geometrical characteristics of simply supported beams.

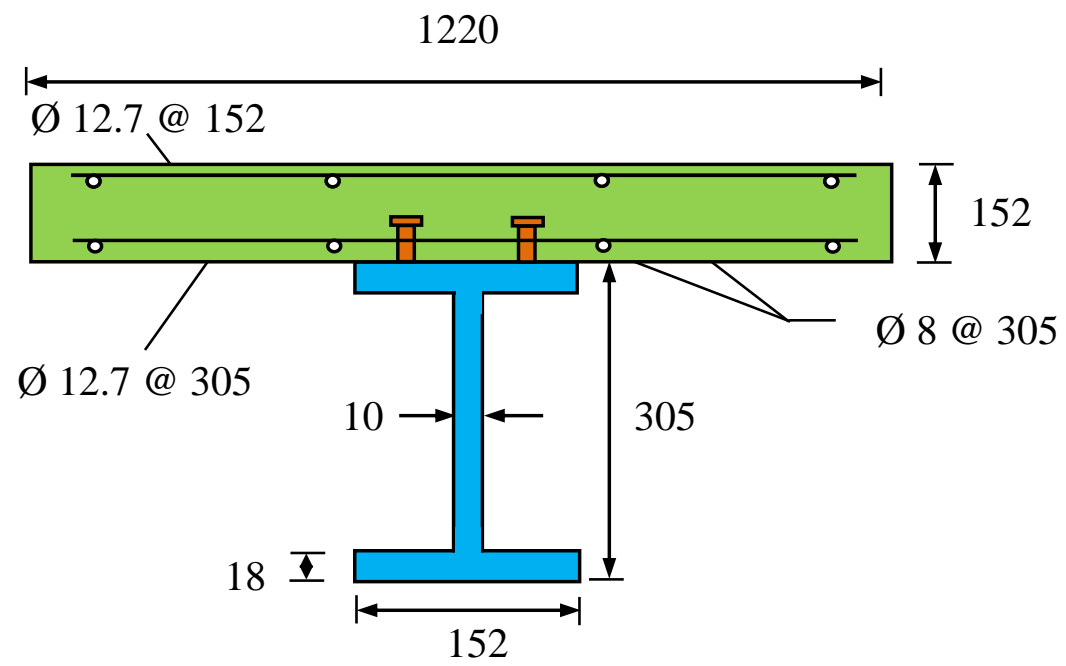

Figure (7): Details of cross section A- A (dimensions in mm).

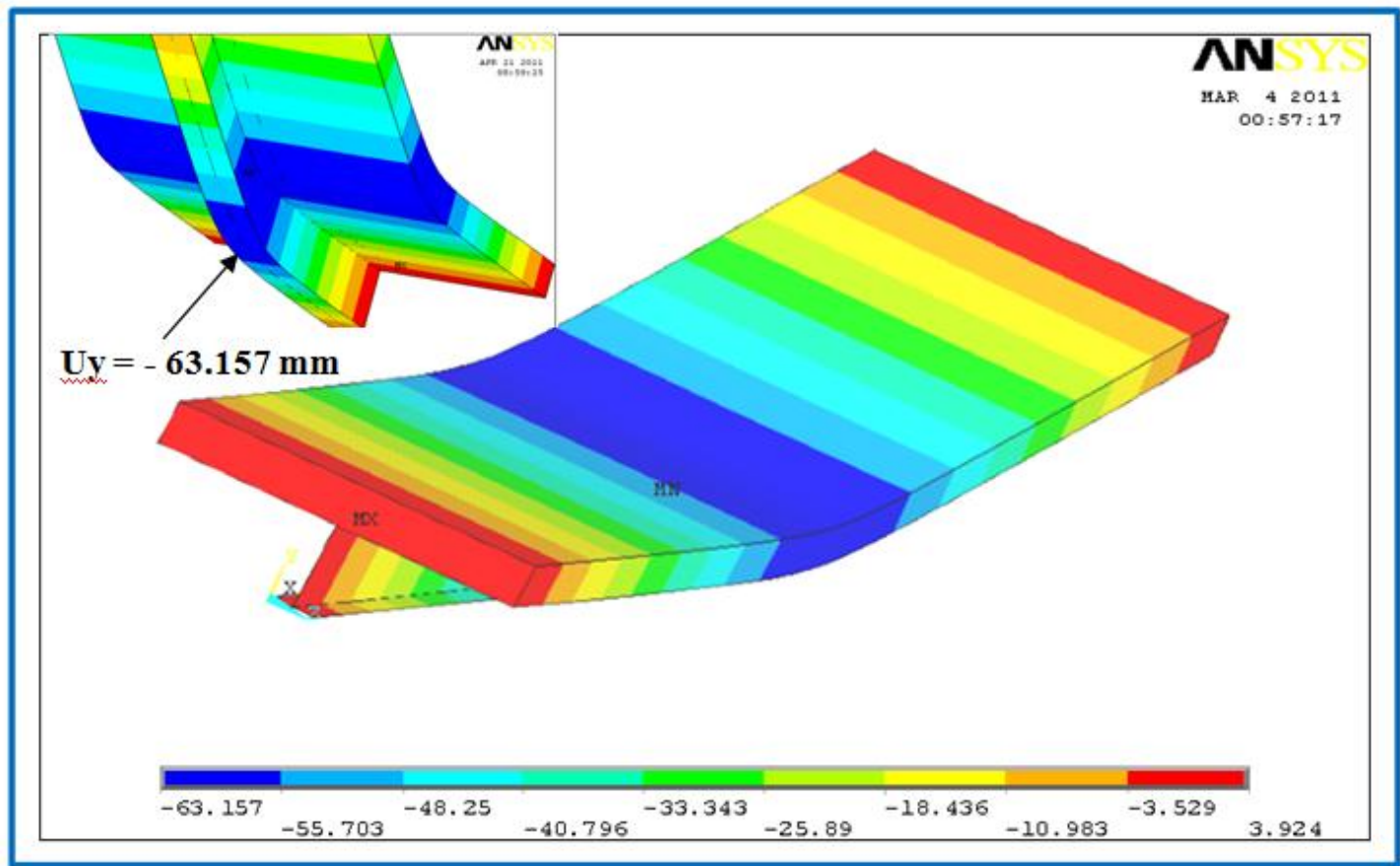

Figure (8): Deflected shape for composite beam at ultimate load. 


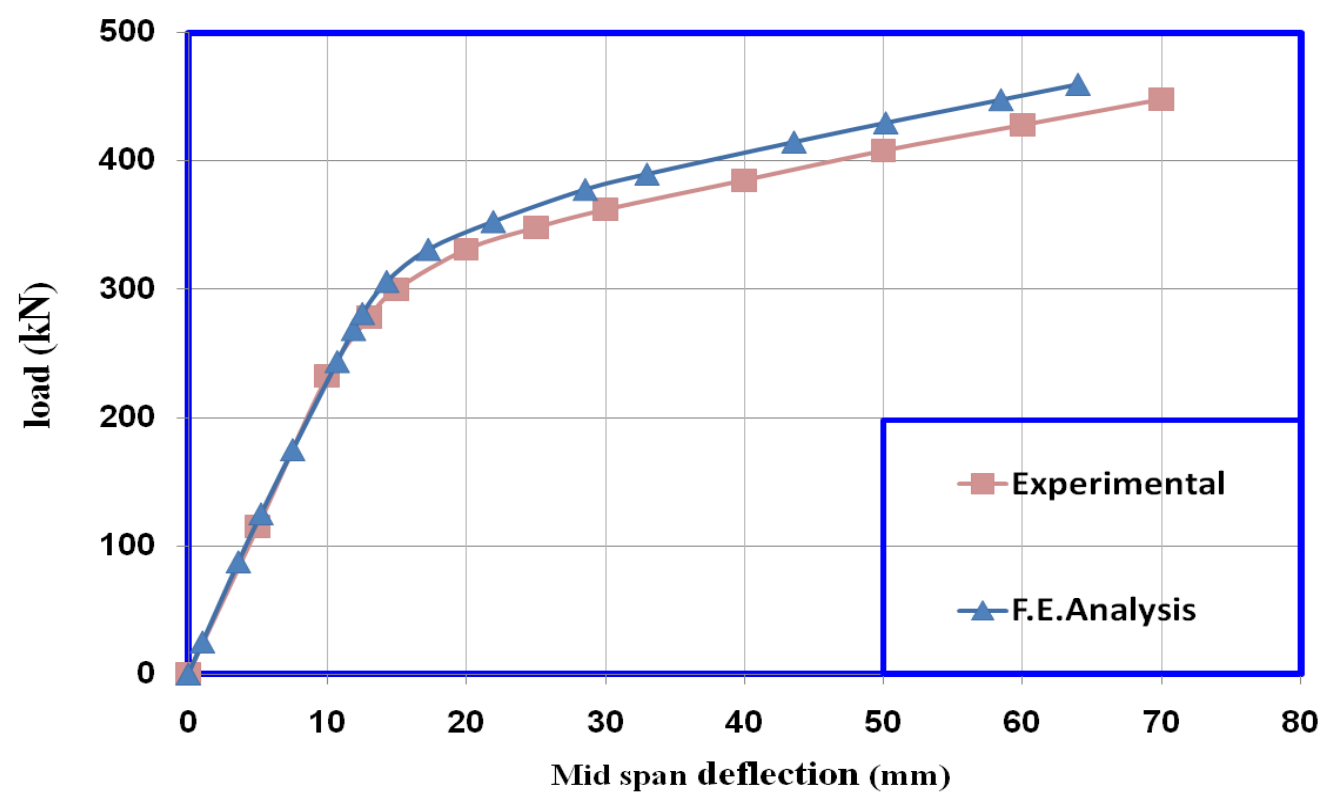

Figure (9): Experimental and analytical load-deflection curves.

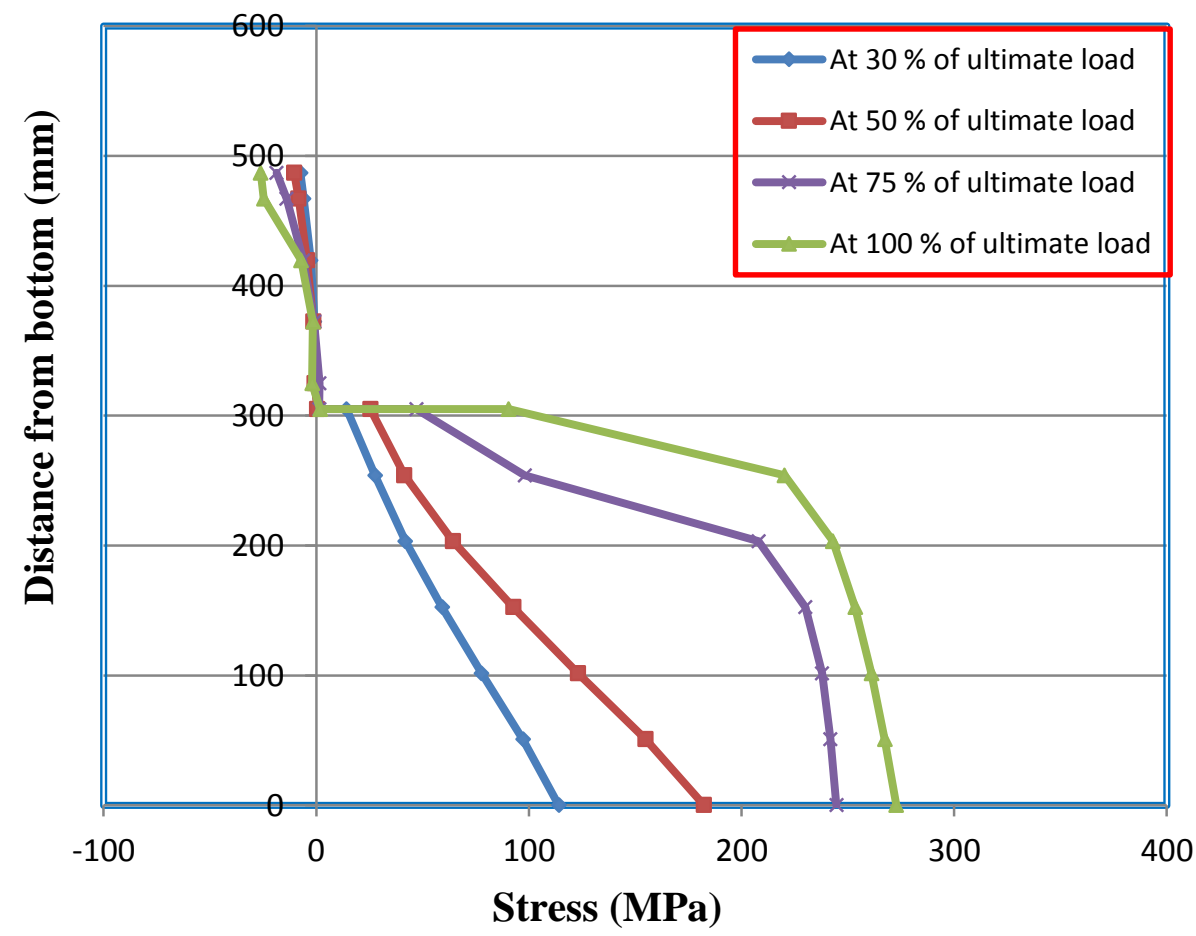

Figure (10): Stress distribution for composite beam along the depth. 


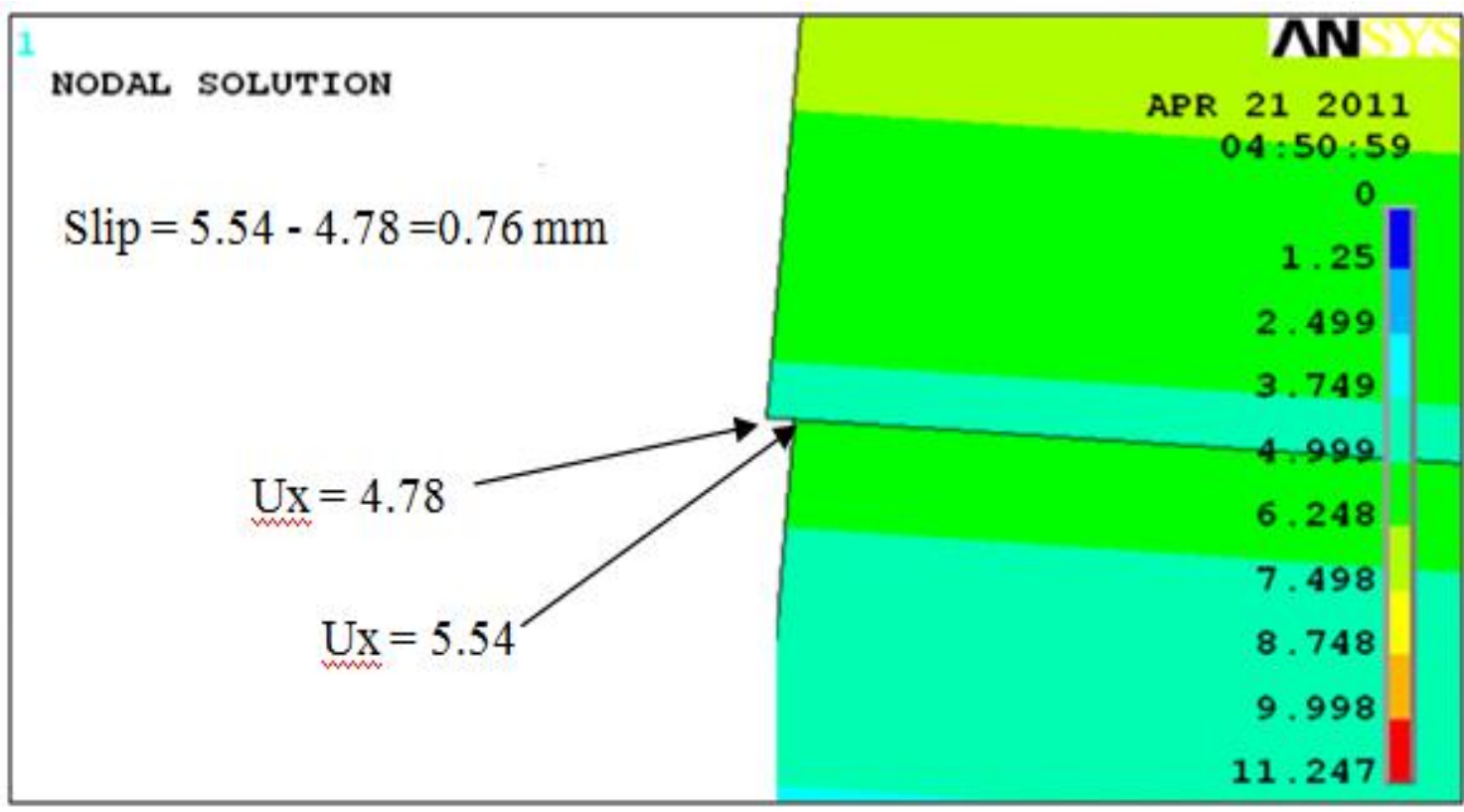

Figure (11): Numerical relative slip between concrete and steel for composite beam.

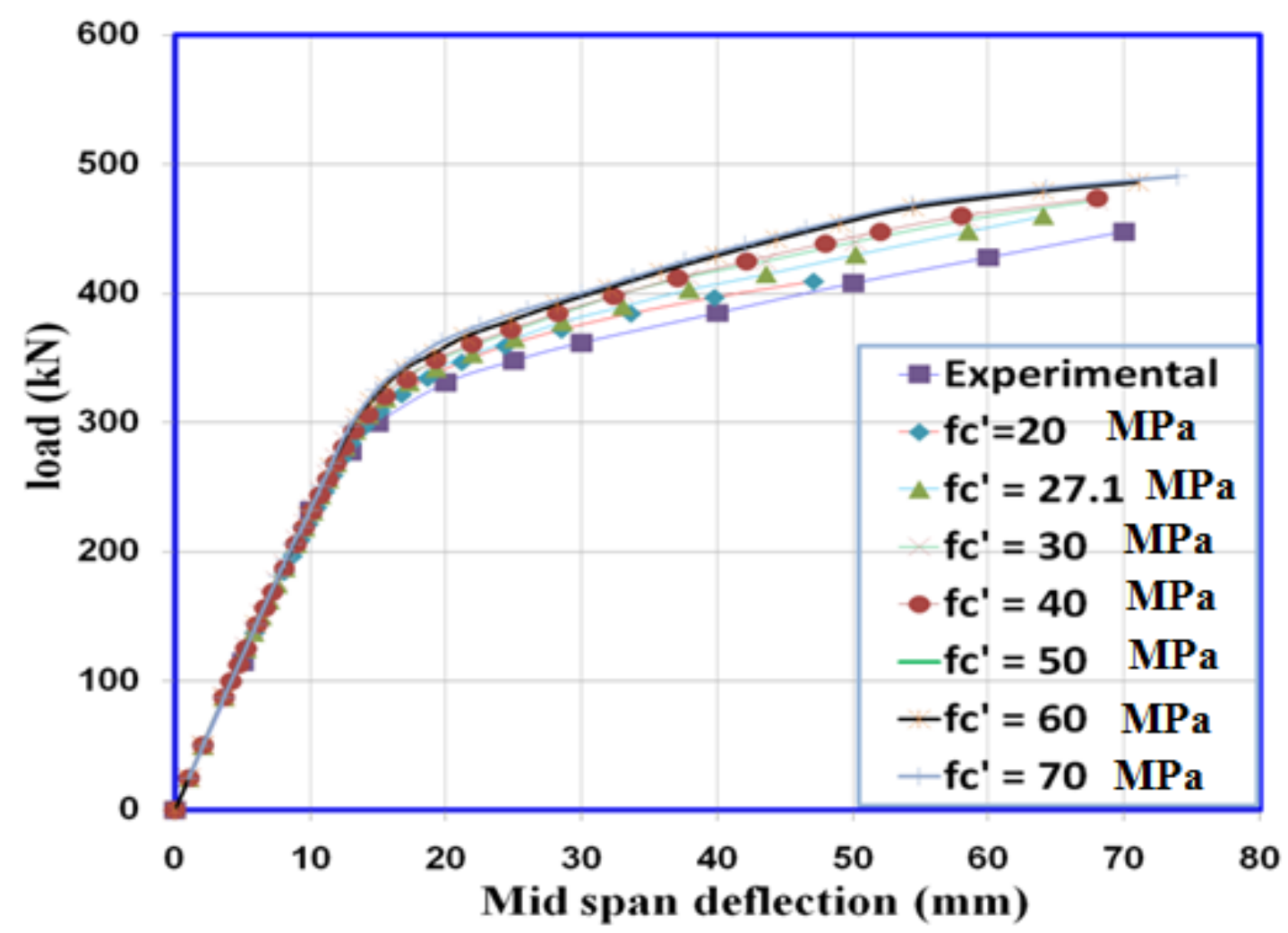

Figure (12): Effect of compressive strength of concrete on the load-deflection behavior for composite beam. 


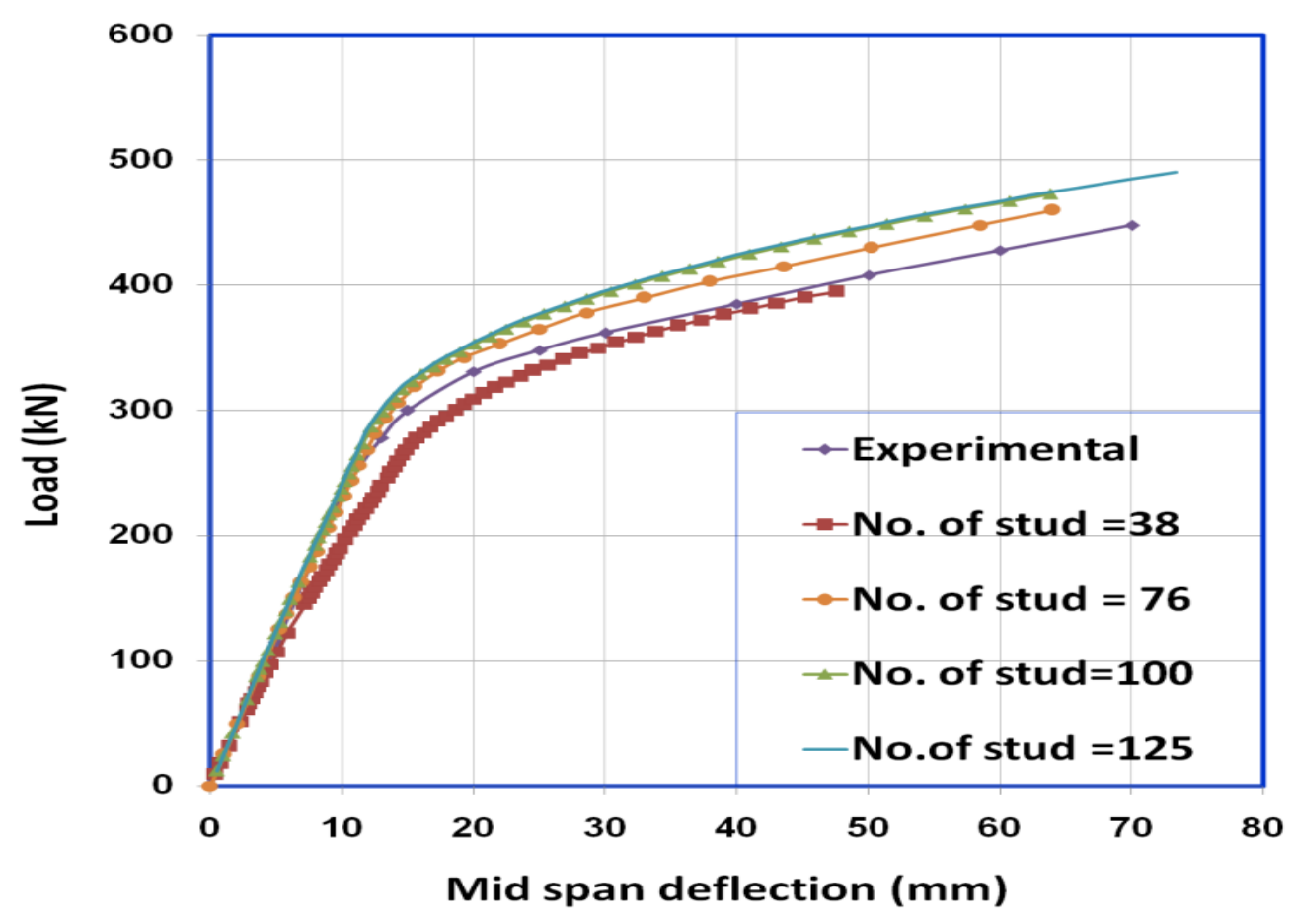

Figure (13): Effect of number of shear connectors on the load-deflection behavior composite beam.

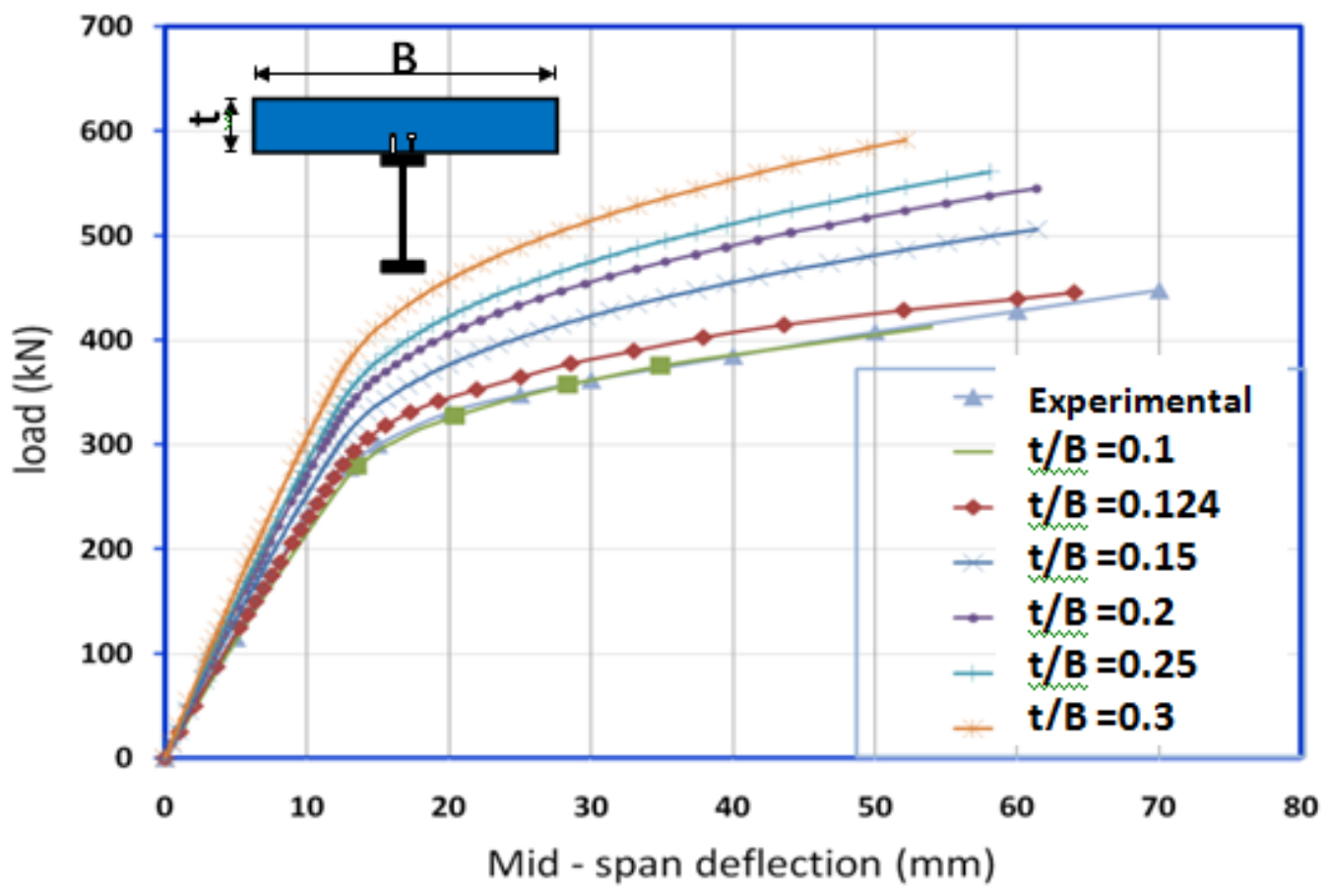

Figure (14): Effect of thickness ratio to width slab concrete on the load-deflection behavior for composite beam. 


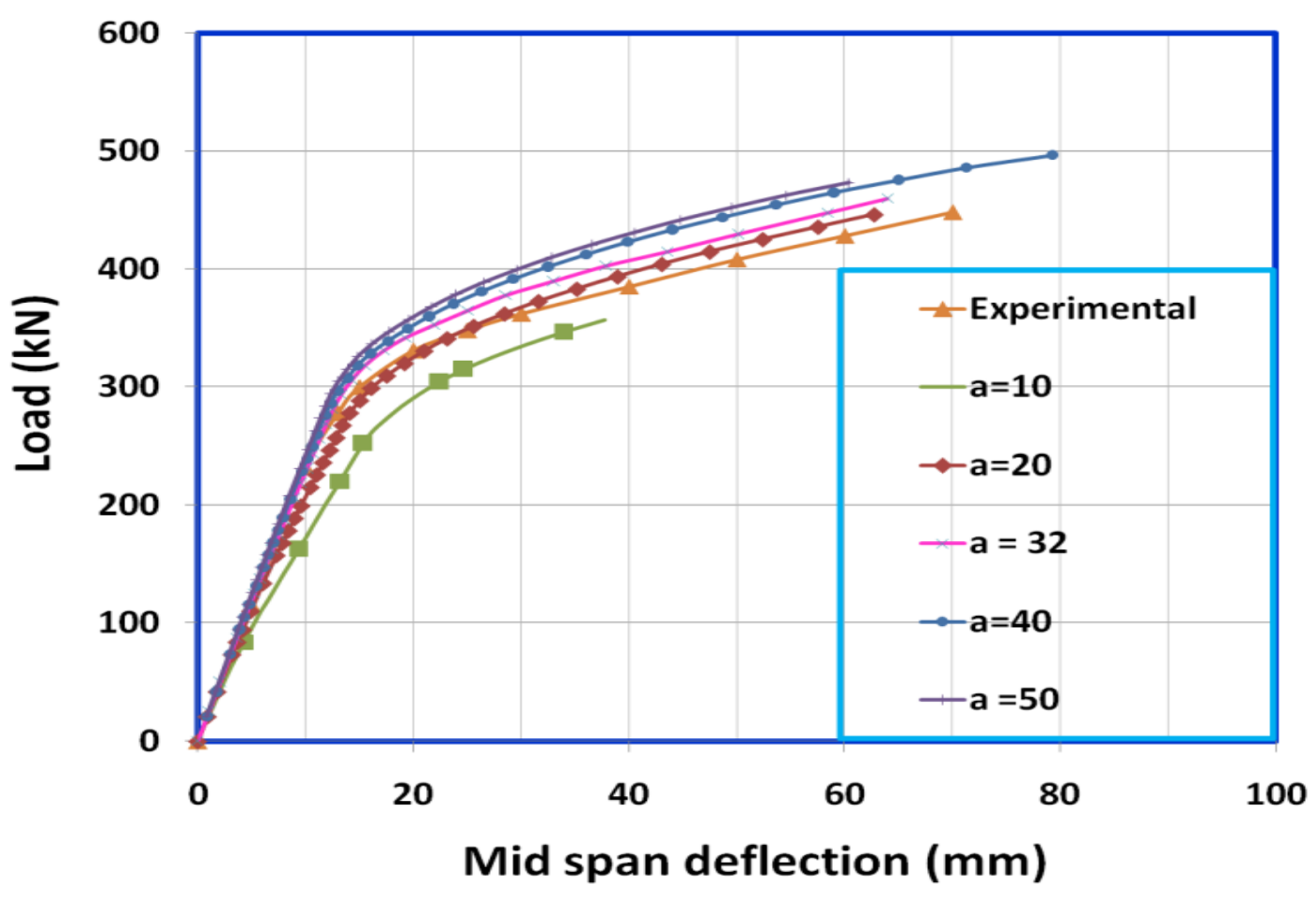

Figure (15): Effect of the strength of shear connector on the load-deflection behavior for composite beam.

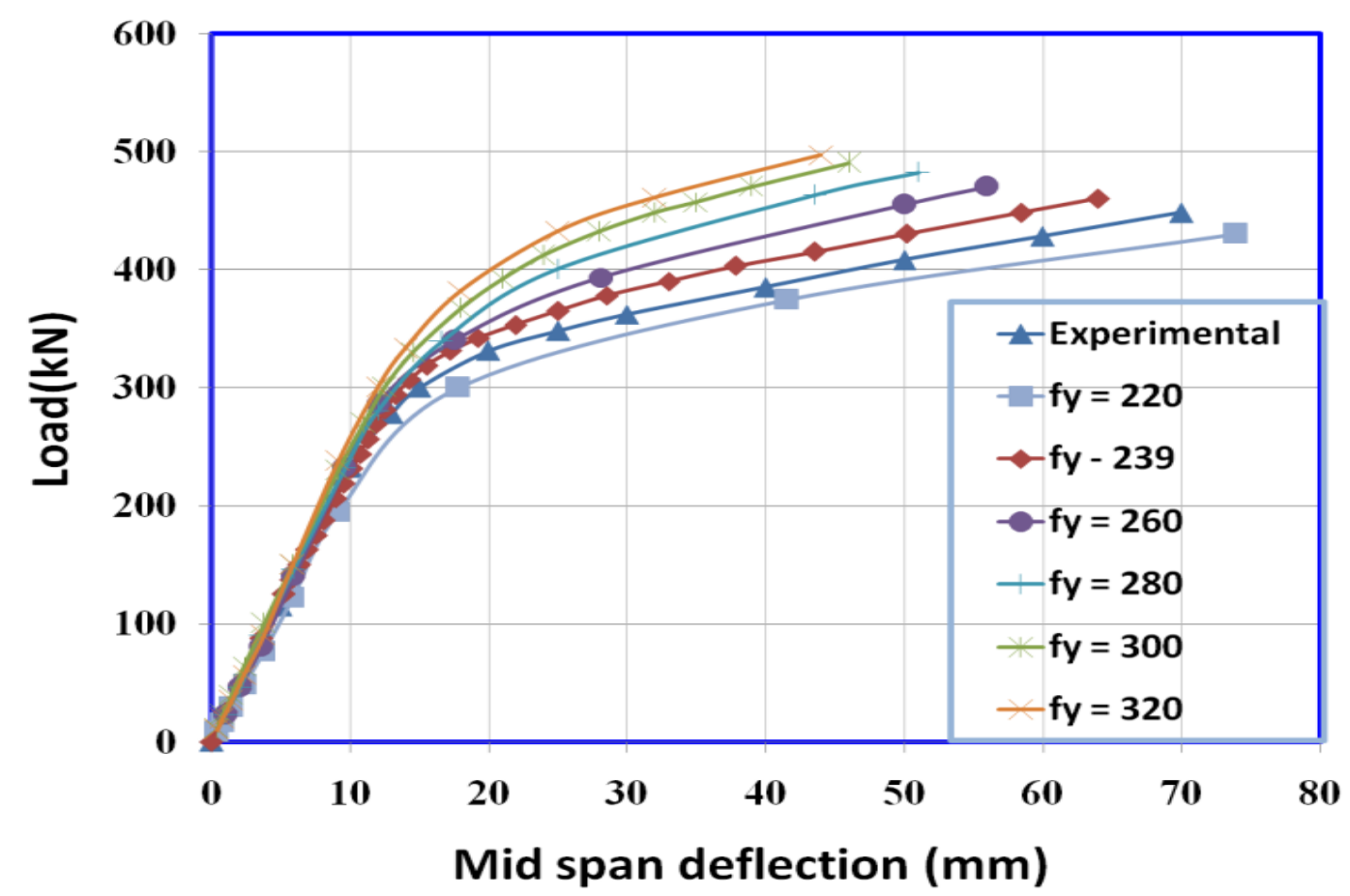

Figure (16): Effect of the yield strength of steel beam on the load-deflection for composite beam. 


\section{التحليل اللاخطي لعتبة مركبة بسيطة الإسناد من الفولاذ - الخرسانة}

$$
\begin{aligned}
& \text { قصي وهاب احمد } \\
& \text { مدرس مساعد } \\
& \text { كلية الهندسة- جامعة ديالى }
\end{aligned}
$$

$$
\text { عامر محمد إبراهيم }
$$

كلية الهندسة- جامعة ديالى

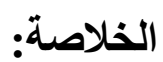

هذا البحث يقدم برنامج التحليلاللاخطياستخدامالعناصرالحددة ANSYSالإصدار 12 والمطور لتحليل عنبة مركبة فولاذ-خرسانة. تتاول هذا العمل نموذج لعنصر محدد ثلاثي الأبعاد. النتائج النظرية لتصرف الحمل-الاود قورنت

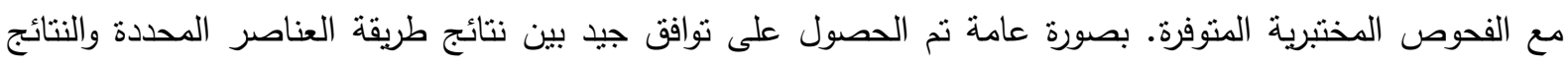

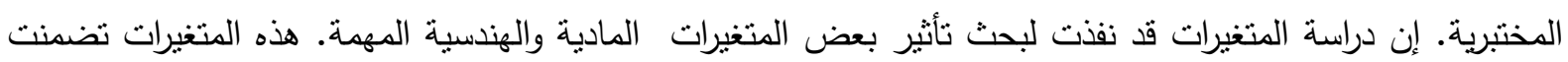
تأثير عدد الروابط القصية ، ومقاومة الانضغاط للكونكريت، نسبة سمك الى عرض البـ البلاطة الخرسانية، الحمل الأقصى

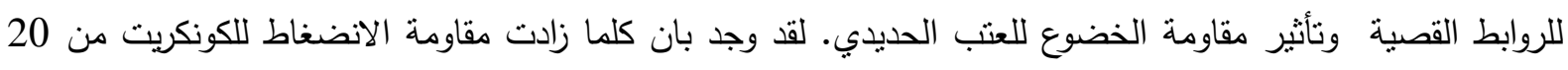
MPa 70 MPa فان الحمل الأقصى يزداد حوالي 20 \% وكذلك بزيادة نسبة سمك الى عرض البلاطة الخرسانية

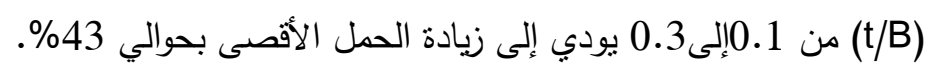

